\title{
$2.25 \mathrm{Cr} 1 \mathrm{Mo}$ 鋼ボイラ伝熱管の実機使用環境下の
}

$$
\begin{aligned}
& \text { 損傷シミュレーション法の開発と寿命評価 } \\
& \text { 中 代 雅 士* } \text { 木 原 重 光** } \\
& \text { 積 田佳 満*** 梶谷 一 郎*** }
\end{aligned}
$$

The Simulation of Damage Property and Life Time Evaluation Method for 2.25Cr1Mo Heat Transfer Tube in Actual Boiler Plants

by

\author{
Masashi NaKashiro*, Shigemitu Kinara**, Yoshimitu Tumita*** \\ and Ichirou KAJIGAYA***
}

The heating tubes, which operate under most adverse conditions of all boiler components, deserve exceptional care about their remaining service lifetime, with particular regard to accumulation of damage due to creep and progress of corrosion due to oxidation. The current practice of such evaluation is to perform appropriate destructive tests on the tubings sampled out of a bundle concerned, but the creep test does not return accurate enough estimates because the damage that has been accumulated in service is yet too small, giving rise to large scattering of data. In addition, there is a matter of rise of metal temperature due to internal formation of steam-induced oxide film, hence degradation of thermal conduction: since the metal temperature can exceed the initially set design operation temperature as the service is prolonged, this increment will have to be incorporated in the creep damage evaluation. Also, rise of effective stress arising from loss of wall thickness due to external formation of scale has to be considered. This report introduces a comprehensive damage assessment simulation program that takes these changes into account and discusses its authenticity on comparison with damage evaluation conducted by TEM.

Key words : Creep, 2.25Cr1Mo steel, Boiler tube, Life assessment, Oxide scale, Steam scale, Heat transfer, Heat conductivity, Simulation

\section{1 緒言}

近年, 日本国内の火力発電設備の多くは, 運転時間 が 10 万時間を超えており設備の老朽化が進んでいる. ボイラ酎熱部材の多くは ASME 設計基準に準じた 10 万時間クリープ強度を中心とした許容応力で設計され ている. この許容応力には安全係数が含まれており， 耐用年数を越えても使用されている. しかし, 耐用年 数を越えたものは設計上の安全係数を消費しているの で, 健全に使用するためには，これら部材の損傷評価, 余寿命評価が重要になる.

ボイラ耐熱部材の中で過熱器管 $(\mathrm{SH})$ と再熱器管 $(\mathbf{R H})$ 等の伝熱管はボイラ構造材の中でも最高温度域 で使用され，クリープと高温酸化による腐食の損傷が 著しい. 現在, 伝熱管はサンプリングが容易なことか ら，破壊試験で寿命評価している。しかし，現状では
実機使用材の損傷が小さい場合が多く，損傷によるク リープ強度低下量が低応力側でクリープデータのばら つきに入り正確な損傷評価ができない。この破壊試験 法を補う手法として透過電顕 (TEM) を用いたミクロ 観察によるクリープ損傷評価技術を開発し, 低損傷域 でも評価できることを報告している.

しかし，これらはいずれも損傷評価であり，正確な 余寿命評価はできない. 正確な余寿命評価を行うため には今後の使用環境変化を考慮した評価が必要である. 使用時間が長くなれば高温腐食によって管肉厚が減少 し, 内圧によるフープ応力が増加すると共に, 内面の 水蒸気酸化スケール成長による熱伝導特性の低下から 金属温度 (メタル温度) が上昇することを考虑しなけ れば, 正確な余寿命評価はできない. 水蒸気酸化スケ ール膜が薄い場合, 温度上昇量は小さくて問題になら

$\dagger$ 原稿受理 平成 5 年 4 月21日 Received Apr. 21, 1993

* 正 会 員 石川島播磨重工業(株)技術研究所 个153 東京都江東区豊洲, Ishikawajima-Harima Heavy Indust. Co. Ltd. Res. Indust., Kotoku, Tokyo, 153

** 石川島播磨重工業(株)技術研究所 $=153$ 東京都江東区豊洲, Ishikawajima-Harima Heavy Indust. Co. Ltd. Res. Indust., Koto-ku, Tokyo, 153

*** 石川島播磨重工業(株)ボイラ事業部, †153 東京都江東区豊洲, Ishikawajima-Harima Heavy Indust. Co. Ltd. Boiler Plant Div., Koto-ku, Tokyo, 153 
ないが，厚くなれば温度上昇量が多くなり，スケール 生成量も増加するので相乗的に損傷汃増加する。これ らのことから伝熱管を正確に余寿命評価するためには， 累積クリープ損傷評価以外に，管内外面の腐食量の評 価, 酸化スケール付着によるメタル温度上昇量評価が 重要である.

そこで本報は，伝熱管の実機使用環境下の損傷特性 を調べ，寿命評価シュミレーション手法を作成し，こ の手法の有効性を検証した結果を報告する.

\section{2 クリープ損傷評価方法の概要}

\section{$2 \cdot 1$ 実機使用環境下の損傷形態のモデル化}

Fig. 1 にボイラ伝熱管の加熱部での使用環境の模式 図を示す：初期状態の $r 1, r 2$ は管寸法の外径と管 肉厚から計算される。使用中に管外表面は燃焼加熱で 高温酸化スケールが生成する．通常，CrMo 鋼の酸 化スケールは 2 層になっており，金属面側に Cr 量の 多いち密な酸化スケール，外面に $\mathrm{Fe}$ 量の多い酸化ス ケールが生成される。.内層と外層の境界付近が旧金属 外表面に相当する。管外表面の酸化による減肉量 $(r 1$ $-r 4)$ は管外径寸法初期值から使用後の外径計測值の 差で求められる. 同様に, 管内面の水蒸気酸化スケー ルも 2 層になっており，層の境界がほぼ元の金属内表 面である．水蒸気酸化スケールはち密であり，使用中 にほとんどはく離しない: 水蒸気酸化スケール厚さは $(r 5-r 6)$ である．管の内外半径の寸法は $r 5$ と $r 4$ に なり，肉厚は $(r 4-r 5)$ となる。

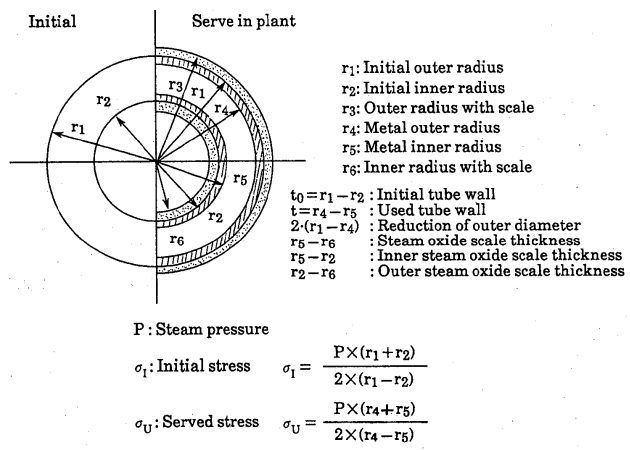

Fig. 1. Schematic model of cross section on tube.

内圧によるフープ応力は平均径式を使用する．酸化 スケールによる管肉厚の減肉で，内圧が同じでもフー プ応力は上昇する. フープ応力の計算式を Fig. 1 に示 す.

$2 \cdot 2$ 水蒸気酸化スケールによるメタル温度上昇量

Fig. 2 に伝熱管の管内外面の温度分布を模式的に示 す。伝熱管の場合，蒸気温度が一定になるように燃焼 火力を制御しているので，内面の蒸気温度 $T_{S}$ を基準 にした温度分布を考える.この温度分布ではメタル温
度 $T_{M}$ は, 内面の水蒸気酸化スケール厚さで上昇し, 外面の酸化スケールの影響は受けない。また，燃焼温 度 $T_{F}$ は温度分布計算には直接必要でない，収熱率 $Q$ は個々のボイラ設計条件で決められる，過熱器管と再 熱器管では值は異なるが，一般的な值を図に示す．蒸 気と管壁との熱伝達率 $\lambda a$ は蒸気圧力, 蒸気流量, 管 内径, 蒸気定圧比熱, 熱伝導率, 粘性係数で決まる. 図に代表的な数值を示す. 同様に $2.25 \mathrm{Cr} 1 \mathrm{Mo}$. 鋼の熱 伝導率 $\lambda m$ は $24\left(\mathrm{kcal} / \mathrm{m} \cdot \mathrm{hr} \cdot{ }^{\circ} \mathrm{C}\right)$, 水蒸気酸化スケ ールの熱伝導率 $\lambda s$ は $1.5\left(\mathrm{kcal} / \mathrm{m} \cdot \mathrm{hr} \cdot{ }^{\circ} \mathrm{C}\right)$ とした 酸化スケールは熱伝導率が鋼よりも小さいので, メ夕 ル温度がその分上昇する。

以上の物性値を用いた管断面の各位置での温度分布 は, Fig. 2 の式で計算される. 外表面の酸化スケール 生成速度は $T_{\text {out }}$ の温度で, 内面の水蒸気酸化生成速 度は $T_{\mathrm{IN}}$ の温度で評価する. クリープ損傷評価は $T_{M}$ の温度で評価する.

\section{$2 \cdot 3$ 燃焼側の酸化スケール成長速度}

一般に高温酸化スケール生成速度は放物線則が用い られる。 しかし, 腐食量に対する温度と時間の関係を 整理するためには, クリープデータ整理と同様に LMP で整理するのがよい。種々のクリープ試験に よって高温酸化スケール生成による試験片の減肉量を LMP 整理した結果を Fig. 3 に示す．6．酸化スケールは 外層スケールがはく離しやすく正確なスケール厚さが はかられないことと, 損傷計算には酸化スケール厚さ よりも管肉厚の減肉量が問題になるので, 減肉量で評 価するのが合理的である，実機計測では酸化スケール を除去したときの管外径を計測し，初期值または設計 仕様による外径寸法との差を求め, 外径減肉量で評価 できる. 図より新材, 実機使用材および溶接継手材等 いずれの材料でも LMP 整理で 1 本の実験回帰曲線式 (1) で酸化減肉量を計算できる. 使用温度と運転時間 を式 (1)に代入すれば, 酸化減肉量を求めることがで きる．また，実測值との結果を合わせるためには，酸 化減肉量 $d$ に係数を乗じることで酸化減肉速度が修 正できる。

$$
T k \cdot(14.68+\log t)=17030+1693 \cdot(\log d)
$$

$$
+267.3 \cdot(\log d)^{2}
$$

ここで, $d=D_{0}-D=2 \cdot(r 1-r 4)$ : 酸化減肉量 $(\mathrm{mm})$ $T k=(273.15+T): T$; 使用平均温度 $\left({ }^{\circ} \mathrm{C}\right)$

$$
t ; \text { 運転時間 }(\mathrm{hr})
$$

である。

管内面の水蒸気酸化スケール付着でメタル温度が上 昇すれば, Fig. 2 に示すように管外表面温度も上昇す る.この温度変化に対する計算手法として, 初期の温 度を基準として温度が上昇した場合の単位計算時間を 式(1)のパラメータ值が同じとして初期温度に対する 


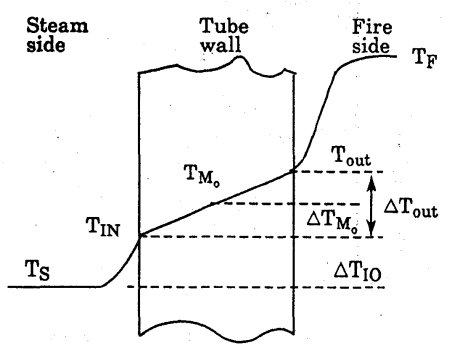

$$
\begin{aligned}
& \Delta T_{\mathrm{IO}}=\frac{Q_{t}}{2 \pi \cdot \lambda_{a} \cdot r_{2}} \\
& \Delta T_{M_{o}}=\frac{Q_{t} \cdot \ln \left(\frac{r_{1}+r_{2}}{2 \cdot r_{2}}\right)}{2 \pi \lambda_{m}} \\
& \Delta T_{\text {out }}=\frac{Q_{t} \ln \left(\frac{r_{1}}{r_{2}}\right)}{2 \pi \lambda_{m}}
\end{aligned}
$$

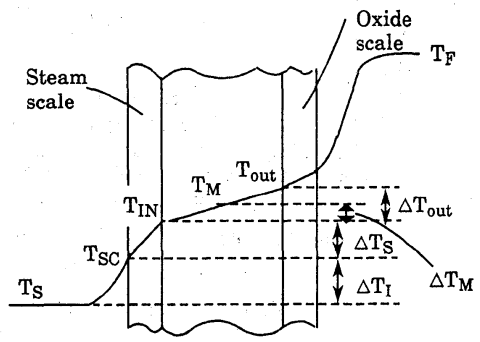

TMo : Design metal temp. $\left({ }^{\circ} \mathrm{C}\right)$

$\mathrm{T}_{\mathrm{S}}$ : Steam temp. $\left({ }^{\circ} \mathrm{C}\right)$ (Constant)

$\mathrm{T}_{\mathrm{F}}$ : Firing temp. $\left({ }^{\circ} \mathrm{C}\right)$

$\mathrm{T}_{\mathrm{IN}}:$ Inner metal temp. $\left({ }^{\circ} \mathrm{C}\right)$

$\mathrm{T}_{\mathrm{M}}:$ Mean metal temp. $\left({ }^{\circ} \mathrm{C}\right)$

$\mathrm{T}_{\text {out }}$ : Outer metal temp. $\left({ }^{\circ} \mathrm{C}\right)$

$\mathrm{T}_{\mathrm{SC}}:$ Inner surface temp. $\left({ }^{\circ} \mathrm{C}\right)$

$Q$ : Heat absorption rate

SH : $40000\left(\mathrm{kcal} / \mathrm{m}^{2} \cdot \mathrm{hr}\right)$

$\mathrm{RH}: 29000\left(\mathrm{kcal} / \mathrm{m}^{2} \cdot \mathrm{hr}\right)$

$\mathrm{Q}_{\mathrm{t}}:$ Uni-heat absorption rate $(\mathrm{kcal} / \mathrm{m} \cdot \mathrm{hr}$ $\mathrm{Q}_{\mathrm{t}}=\mathrm{Q} \times \pi \times 2 \times \mathrm{r}_{1}$

$\lambda_{a}:$ Inner side heat transfer ratio

$\mathrm{SH}: 4300\left(\mathrm{kcal} / \mathrm{m}^{2} \cdot \mathrm{hr} \cdot{ }^{\circ} \mathrm{C}\right)$

$\mathrm{RH}: 1100\left(\mathrm{kcal} / \mathrm{m}^{2} \cdot \mathrm{hr} \cdot{ }^{\circ} \mathrm{C}\right)$

$\lambda_{\mathrm{m}}$ : Heat conductivity of steel

$2.25 \mathrm{Cr} 1$ Mo steel $24000\left(\mathrm{kcal} \cdot \mathrm{mm} / \mathrm{m}^{2} \mathrm{hr} \cdot \mathrm{C}\right)$

$\lambda_{\mathrm{S}}$ : Heat conductivity of scale $1.5\left(\mathrm{kcal} / \mathrm{m} \cdot \mathrm{hr} \cdot{ }^{\circ} \mathrm{C}\right)$

$$
\begin{gathered}
\Delta T_{I}=\frac{Q_{t}}{2 \pi \cdot \lambda_{a} \cdot r_{6}} \\
\Delta T_{S}=\frac{Q_{t} \cdot \ln \left(r_{5} / r_{6}\right)}{2 \pi \cdot \lambda_{S}} \\
\Delta T_{M}=\frac{Q_{t} \cdot \ln \left(\frac{r_{4}+r_{5}}{2 \cdot r_{5}}\right)}{2 \pi \cdot \lambda_{m}} \\
\Delta T_{\text {out }}=\frac{Q_{t} \ln \left(\frac{r_{4}}{r_{5}}\right)}{2 \pi \cdot \lambda_{m}}
\end{gathered}
$$

$$
\begin{aligned}
& \mathrm{T}_{\mathrm{S}}=\mathrm{T}_{\mathrm{Mo}_{0}}-\Delta \mathrm{T}_{\mathrm{Mo}}-\Delta \mathrm{T}_{\mathrm{IO}} \\
& \mathrm{T}_{\mathrm{SC}}=\mathrm{T}_{\mathrm{S}}+\Delta \mathrm{T}_{\mathrm{I}} \\
& \mathrm{T}_{\mathrm{IN}}=\mathrm{T}_{\mathrm{S}}+\Delta \mathrm{T}_{\mathrm{I}}+\Delta \mathrm{T}_{\mathrm{S}}: \\
& \mathrm{T}_{\mathrm{M}}=\mathrm{T}_{\mathrm{S}}+\Delta \mathrm{T}_{\mathrm{I}}+\Delta \mathrm{T}_{\mathrm{S}}+\Delta \mathrm{T}_{\mathrm{M}}: \\
& \mathrm{T}_{\text {out }}=\mathrm{T}_{\mathrm{S}}+\Delta \mathrm{T}_{\mathrm{I}}+\Delta \mathrm{T}_{\mathrm{S}}+\Delta \mathrm{T}_{\text {out }}:
\end{aligned}
$$

Steam scale thickness evaluation

Creep damage evaluation

Oxide scale thickness evaluation

Fig. 2. Schematic diagram of temperature distribution.

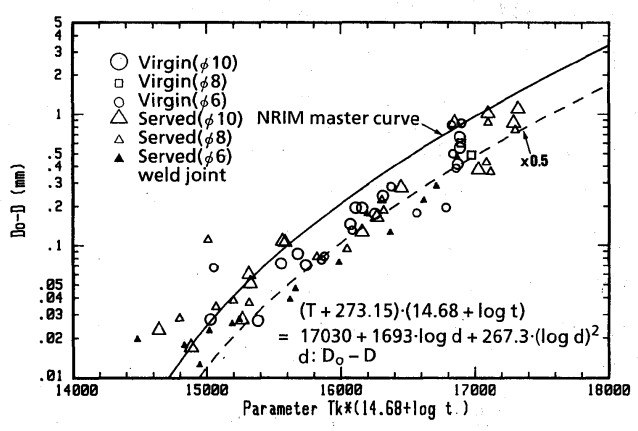

Fig. 3. Relationship between the specimen diameter reduction by oxide scale and L. M. parameter for 2.25Cr1Mo steel in air atmosphere test.

等価時間を求め,この等価時間を積算した時間で酸化 減肉量を計算する。

\section{$2 \cdot 4$ 管内面水蒸気酸化成長速度}

水蒸気酸化スケール生成速度は, Fig. 4 の EPRI 報 告デー夕を採用する。. 図には酸化スケールが内層の $\mathrm{Cr}$ 量が高い旧金属面に形成されたものと，全体の酸 化スケール厚さを示す．管の寿命評価には，全層の水 蒸気酸化スケール厚さがメ夕ル温度上昇に影響を与え るとして計算する，スケール生成速度は平均值を使用 する，それぞれの計算式は 1 次式で式 (2)，(3)に示す。 高温酸化と同様に水蒸気酸化速度の修正は標準式に係 数を乗じる方法を用いた。ここで，管肉厚の減少量は 内層スケール厚さに等しいとして計算する.

$$
\begin{aligned}
& \log d_{\mathrm{IN}}=2.15 \times 10^{-4} \cdot P_{a r}-5.978 \\
& \log d_{T}=2.11 \times 10^{-4} \cdot P_{a r}-5.503 \\
& \text { ここで, } d_{\mathrm{IN}}=(r 5-r 2): \text { 内層スケール厚さ }(\mu) \\
& =\text { 減肉量 } \\
& d_{T}=(r 5-r 6): \text { 全層スケール厚さ }(\mu)
\end{aligned}
$$




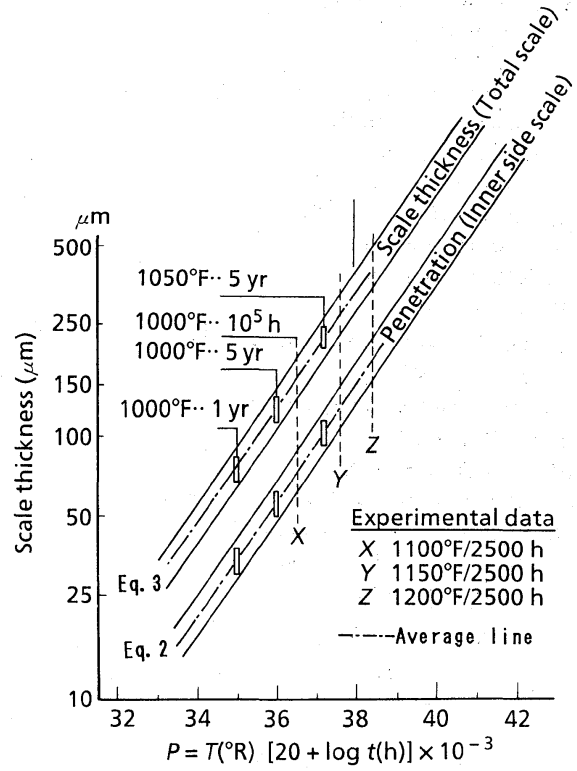

Fig. 4. Steam-side oxidation growing thickness for $1 \sim 3 \% \mathrm{Cr}$ steel. (EPRI Data)

$$
\begin{aligned}
& P_{a r}:(T+491.67) \times(20+\log t) \\
& t: \text { 使用時間 }(\mathrm{hr}) \\
& T: \text { Operation Temprature }\left({ }^{\circ} \mathrm{F}\right)
\end{aligned}
$$

温度変化に対する計算手法は, 外側の酸化スケール と同様に初期の温度を基準として温度が上昇した場合 の単位計算時間を式 (2), (3) パラメータ值が同じとし て, 初期温度に対する等価時間を求め, この等価時間 を積算した時間で酸化減肉量を計算する.

\section{$2 \cdot 5$ クリープ損傷評価}

NRIM クリープデータシートをLMP で整理した結 果をFig. 5 に示す. この)データには 10 万時間を超え るクリープ試験結果が多数含まれていること, 試験片 の直径が $6 \mathrm{~mm}$ と比較的小さいので, 長時間側のデー 夕には, クリープ試験中の酸化による強度低下が著し い．その結果, ASME の許容応力と $99 \%$ 下限值のク リープ強度が低応力側で交差している. 式 (1) を用い て酸化の影響を修正したデー夕整理結果をFig. 6 に示 す. 従来クリープ試験中の酸化の影響は, 実機使用環 境下でも酸下の影響を受けるので特に問題視はされて いない. しかし, 実機使用環境下での酸化と温度加速

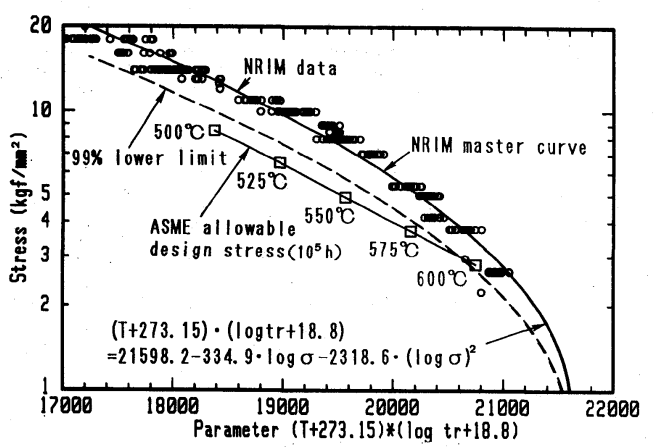

Fig. 5. Stress versus L. M. parameter relations of STBA24 in NRIM creep data sheet and ASME desing allowable stresses.

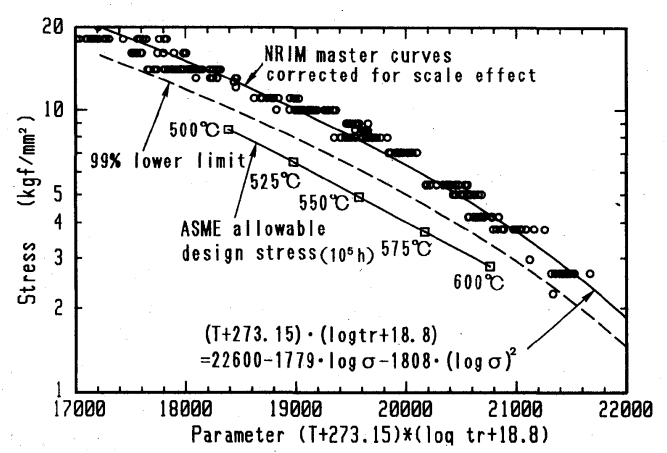

Fig. 6. Stress versus L. M. parameter curves and creep data of STBA24 (NRIM) for calculating oxide scale effect.

クリープ試験下の酸化がクリープ強度に与える影響は 異なるので，本報のように酸化の影響を考慮した損傷 評価を行う場合には, ”クリープ強度も酸化の影響を除 いたデー夕を用いるべきであり，その方が精度良く寿 命評価できると考えられる.

\section{3 計算および解析結果の検討}

\section{3・1 SH, RH モデルの損傷評価}

代表的なボイラ伝熱管の損傷評価を行うために，採 用した計算条件を Table I に示す. SH では, 設計肉 厚を $\left(t_{s r}+0.5\right) \mathrm{mm}$ とし，製造時に $10 \%$ 増しの管を

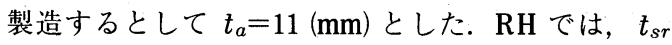
$=2.3 \mathrm{~mm}$ に対して，管製造条件，曲げ加工性および 溶接施工条件など考慮して最小管肉厚を $3.5 \mathrm{~mm}$ とし,

\begin{tabular}{|c|c|c|c|c|c|c|c|c|c|}
\hline \multirow{2}{*}{ STBA 24} & \multirow{2}{*}{ Location } & \multirow{2}{*}{$\begin{array}{l}\text { Metal } \\
\text { temp. } \\
\left({ }^{\circ} \mathrm{C}\right)\end{array}$} & \multirow{2}{*}{$\begin{array}{c}\sigma_{a} \\
\left(\mathrm{kgf} / \mathrm{mm}^{2}\right)\end{array}$} & \multirow{2}{*}{$\begin{array}{c}P \\
\left(\mathrm{kgf} / \mathrm{cm}^{2}\right)\end{array}$} & \multirow{2}{*}{$\begin{array}{c}D \\
(\mathrm{~mm})\end{array}$} & \multicolumn{2}{|c|}{ Wall thickness (mm) } & \multirow{2}{*}{$\begin{array}{l}\text { Corrosion } \\
\text { allowance } \\
(\mathrm{mm})\end{array}$} & \multirow{2}{*}{$\begin{array}{c}\text { Actual initial } \\
\text { stress } \\
\left(\mathrm{kgf} / \mathrm{mm}^{2}\right)\end{array}$} \\
\hline & & & & & & $t_{S R}$ & $t_{a}$ & & \\
\hline \multirow{2}{*}{$\mathbf{T}-22$} & $\mathrm{SH}$ & 570 & 3.9 & 197 & 45 & 9.5 & 11.0 & 1.5 & 3.04 \\
\hline & $\mathrm{RH}$ & 570 & 3.9 & 43 & 45 & 2.3 & 3.85 & 1.55 & 2.30 \\
\hline
\end{tabular}
$10 \%$ 増しの管を製造するとして $t_{a}=3.85 \mathrm{~mm}$ とした.

Table I. Design conditions and tube dimension used for calculation of life fraction.

$\sigma_{a}:$ MITI allowable stress. $\quad P$ : Steam pressure $\left(\mathrm{kg} / \mathrm{cm}^{2}\right) . \quad D:$ Tube diameter $(\mathrm{mm})$

$t_{s R}=(P \times D) /\left(P+200 \sigma_{a}\right)+0.005 \times D$ [Design required thickness]. $t_{a}:$ Actual thickness 
損傷計算は初期值から 500 時間ピッチの間隔で管内 外の酸化スケール生成量を計算し，それから Fig. 2 に 示したように断面各位置での温度, 酸化スケールによ る減肉量を考慮した応力, これらの温度, 応力に対応 したクリープ破断時間 $\left(t_{r}\right)$ によるクリープ損傷比 $(t$ $\left./ t_{r}\right)$ を計算し，線形損傷則 $\left(D_{c}=\Sigma t / t_{r}\right)$ で積算した. また, オーバヒートの効果を観るために, 初期温度を $570^{\circ} \mathrm{C}$ の設計温度に対して $10,20^{\circ} \mathrm{C}$ 温度上昇した場 合の特性についても計算した.

Fig. 7 に使用時間によるメタル温度上昇量を示す. $\mathrm{SH}$ と RH では $\mathrm{SH}$ の方が約 2 倍の值になる。これは Fig. 8 に酸化スケール厚さと温度上昇の関係を示すよ

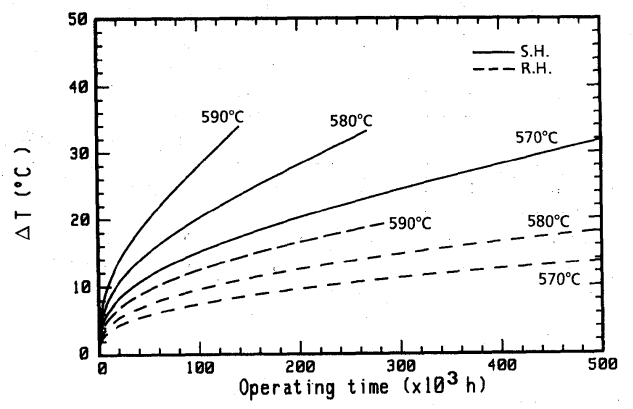

Fig. 7. Increase of metal temperature by oxidation for superheater and reheater tubes of STBA24. $\left(570,580,590^{\circ} \mathrm{C}\right)$

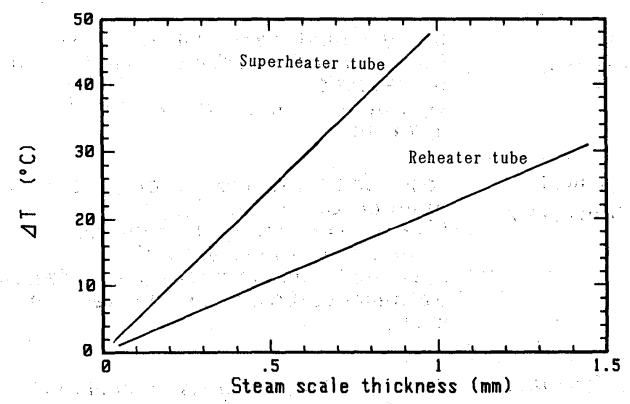

Fig. 8. Increase of metal temperature by steam oxidation thickness for superheater and reheater tubes of STBA24.

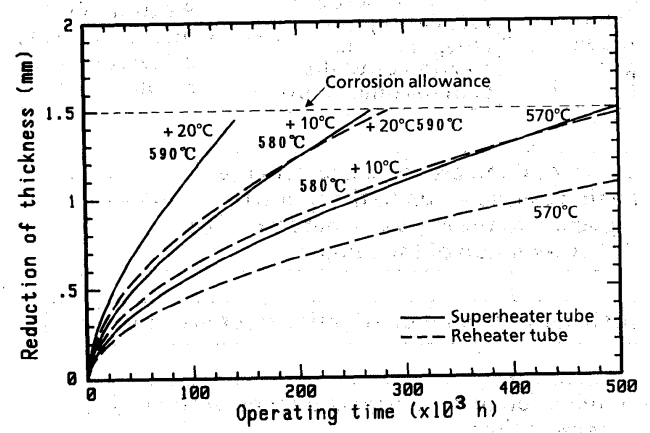

Fig. 9. Reduction of metal wall thickness by oxidation for superheater and reheater tubes of STBA24. $\left(570,580,590^{\circ} \mathrm{C}\right)$
うに，収熱率の差による温度上昇量の差が酸化スケー ル成長速度の差となり, 相乗効果で上昇温度差が広 がったと考えられる。

Fig. 9 に使用時間による管肉厚の減肉量を示す．温 度上昇量に対応して減肉するので, SH の方が RH よ りも減肉速度が早い. SH ではオーバヒートがなけれ ば 50 万時間程度まで設計許容肉厚を保てる．RH で は，同じ腐食代であっても酸化スケールによる温度上 昇量が少なく，オーバヒートしないかぎり要求肉厚は 切らないようである.

SH と RH のクリープ損傷計算結果を Fig. 10 と Fig. 11 にそれぞれ示す. 図中に従来法の Fig. 5 の NRIM クリープデータを用いて初期条件からクリー プ損傷を計算した寿命消費線を示す。この寿命消費線 とクリープ損傷計算曲線は，損傷比が小さい場合には ほぼ同じような結果であるが，損傷比が 0.3 以上にな るとクリープ損傷計算曲線の方が寿命消費が早くなる. このことは，損傷比が大きくなるほど温度上昇量が大 きく，初期条件による計算よりも余寿命が短くなるの で，従来の評価法では非安全側の評価を行う可能性が ある。これは，長時間使用すれば水蒸気酸化膜が厚く

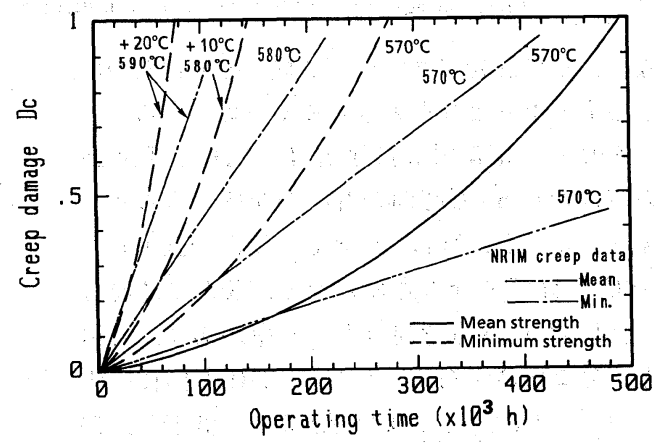

Fig. 10. Creep damage variation with operating time for average and $99 \%$ minimum creep strength on $\mathrm{SH}$ tube. (Base $570^{\circ} \mathrm{C}$. Over heat $580,590^{\circ} \mathrm{C}$ )

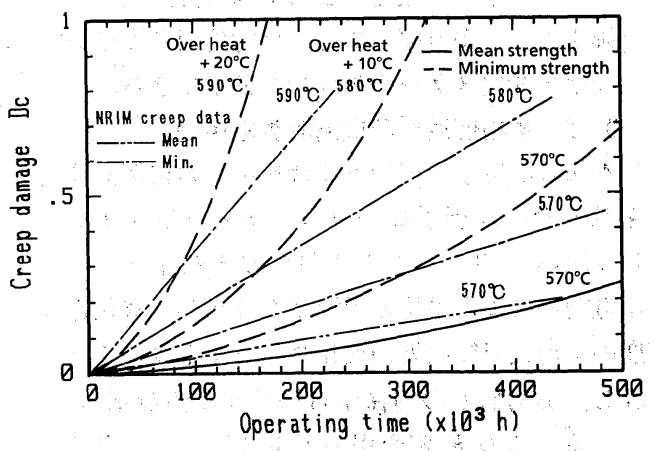

Fig. 11. Creep damage variation with operating time for average and $99 \%$ minimum creep strength on $\mathrm{RH}$ tube. (Base $570^{\circ} \mathrm{C}$. Over heat $580,590^{\circ} \mathrm{C}$ ) 
Table II. Creep damage calculation results for varieous service tubes.

\begin{tabular}{|c|c|c|c|c|c|c|c|c|c|c|c|c|c|c|}
\hline \multirow{2}{*}{$\begin{array}{c}\text { Boiler } \\
\text { unit }\end{array}$} & \multirow{2}{*}{$\begin{array}{c}\text { Operation } \\
\text { service } \\
\text { time }\end{array}$} & \multirow{2}{*}{$\begin{array}{c}\text { Service } \\
\text { temp. }{ }^{* 1}\end{array}$} & \multirow{2}{*}{$\begin{array}{l}\text { Service } \\
\text { pressure }\end{array}$} & \multicolumn{2}{|c|}{ Initial size } & \multicolumn{2}{|c|}{ Served size } & \multirow[b]{2}{*}{$T_{s r}$} & \multirow{2}{*}{$\begin{array}{c}\text { Tube } \\
\text { damage } \\
\text { cond. }{ }^{* 2}\end{array}$} & \multirow{2}{*}{$\begin{array}{l}\text { Oxid } \\
\text { factor }\end{array}$} & \multirow{2}{*}{$\begin{array}{l}\text { Steam } \\
\text { oxid } \\
\text { factor }\end{array}$} & \multirow[b]{2}{*}{$D_{c}{ }^{* 3}$} & \multirow[b]{2}{*}{$D_{c} 99 * 4$} & \multirow[b]{2}{*}{$D N_{s b}$} \\
\hline & & & & $\begin{array}{c}\text { Outer } \\
\text { dia. }\end{array}$ & $\begin{array}{l}\text { Wall } \\
\text { thick }\end{array}$ & $\begin{array}{c}\text { Outer } \\
\text { dia. }\end{array}$ & $\begin{array}{l}\text { Wall } \\
\text { thick. }\end{array}$ & & & & & & & \\
\hline Unit & $(\mathrm{hr})$ & $\left(\mathrm{C}^{\circ}\right)$ & (atm) & $(\mathrm{mm})$ & $(\mathrm{mm})$ & $(\mathrm{mm})$ & $(\mathrm{mm})$ & $(\mathrm{mm})$ & & & & & & \\
\hline A-1 RH & \multirow[t]{2}{*}{144768} & \multirow[t]{2}{*}{593} & \multirow[t]{2}{*}{41.0} & \multirow[t]{2}{*}{50.8} & \multirow[t]{2}{*}{5.50} & 49.63 & 4.43 & \multirow[t]{2}{*}{3.10} & I & 0.68 & 1.40 & 0.16 & 0.37 & 0.50 \\
\hline A-2 RH & & & & & & 49.88 & 4.89 & & I & 1.07 & 1.00 & 0.09 & 0.21 & 0.50 \\
\hline B-1 RH & \multirow[t]{4}{*}{99800} & \multirow[t]{4}{*}{580} & \multirow[t]{4}{*}{55.0} & \multirow[t]{4}{*}{57.0} & \multirow[t]{4}{*}{4.40} & 54.00 & 2.72 & \multirow[t]{4}{*}{3.50} & $\mathrm{EI}$ & 3.59 & 0.85 & 0.55 & 1.84 & 0.65 \\
\hline B-2 RH & & & & & & 56.20 & 3.83 & & EI & 0.96 & 0.81 & 0.20 & 0.61 & 0.30 \\
\hline B-3 RH & & & & & & 53.60 & 2.57 & & $\mathrm{EF}$ & 4.07 & 0.62 & 0.69 & 2.39 & 0.50 \\
\hline B-4 RH & & & & & & 56.00 & 2.57 & & $\mathrm{EF}$ & 1.20 & 0.66 & 0.21 & 0.66 & 0.22 \\
\hline C-1 RH & \multirow[t]{4}{*}{49840} & \multirow[t]{4}{*}{631} & \multirow[t]{4}{*}{35.0} & \multirow[t]{4}{*}{45.0} & \multirow[t]{4}{*}{4.00} & 43.00 & 2.51 & \multirow[t]{4}{*}{3.50} & OI & 0.74 & 0.76 & 0.48 & 1.17 & 0.88 \\
\hline C-2 RH & & & & & & 44.20 & 3.37 & & OI & 0.29 & 0.35 & 0.30 & 0.70 & 0.73 \\
\hline C-3 RH & & & & & & 40.90 & 1.62 & & OF & 1.48 & 0.50 & 0.95 & 2.64 & 0.72 \\
\hline $\mathrm{C}-4 \mathrm{RH}$ & & & & & & 43.50 & 2.98 & & OF & 0.54 & 0.41 & 0.39 & 0.92 & 0.51 \\
\hline D-1 RH & 120752 & 578 & 45.0 & 45.0 & 4.40 & 43.89 & 3.44 & 3.30 & I & 0.75 & 1.34 & 0.13 & 0.33 & 0.73 \\
\hline E-1 SH & 144768 & 580 & 149.0 & 50.8 & $10: 45$ & 50.16 & 9.81 & 8.27 & I & 0.42 & 1.00 & 0.24 & 0.66 & 0.65 \\
\hline F-1 SH & 167700 & 570 & 195.0 & 63.5 & 14.30 & 63.07 & 13.42 & 12.65 & I & 0.34 & 1.00 & 0.20 & 0.61 & 0.26 \\
\hline G-1 SH & 30000 & 622 & 200.0 & 54.0 & 12.10 & 53.20 & 11.42 & 10.55 & OF & 0.63 & 1.00 & 1.00 & 3.10 & 0.99 \\
\hline $\mathrm{G}-2 \mathrm{SH}$ & & 602 & & & & 53.50 & 11.50 & & OI & 0.40 & 1.00 & 0.32 & 0.93 & 0.42 \\
\hline
\end{tabular}

Note : ${ }^{* 1}$ Service Temperature are decided by microstructure changing.

*2 I : Integrity. E: Erosion. O: Over heat. F: Failure.

*3 Creep damage calculated by average creep strength.

*4 Creep damage calculated by $99 \%$ lower creep strength

なり，その影響がクリープ試験中の酸化減肉に よる応力上昇よりも大きくなるためである.

クリープ損傷計算によれば， $\mathrm{SH}$ では約 28 万時間から 50 万時間の寿命が期待できるが, オーバヒートに対しては著しく寿命が低下し， $10^{\circ} \mathrm{C}$ 上昇で半分の寿命になる． $\mathrm{RH}$ では通常 の使用では 50 万時間以上の寿命があり，実用 上十分な寿命がある。しかし，SH と同様に才 ーバヒートに対しては寿命が著しく低下し，10 ${ }^{\circ} \mathrm{C}$ 上昇で $\mathrm{SH}$ 同様に寿命は半分になる:この 計算結果から，伝熱管の寿命評価は設計使用条 件によるクリープ損傷計算よりも，平均使用温 度を正確に求め, 酸化による減肉と温度上昇を 評価することが重要である. 平均使用温度は組 織観察と酸化スケール生成量で推定できゔ.

\section{$3 \cdot 2$ 実機使用材の損傷計算応用例}

本報の計算手法で種々実機使用材の損傷計算 を試みた．評価手順のブローチャートを Fig. 12 に示す. サンプリング材の検査結果から, 組織観察による平均使用温度を算出し, 酸化速 度の平均式で管内外の酸化スケール生成量を計 算し，実測値との関係から修正速度係数 $K$ を 求める. この $K$ 值を用いて再度初めから累積 損傷和が 1 になるまでの時間とスケール厚さ， 管肉厚, メタル温度および累積クリープ損傷和 の関係を求める.

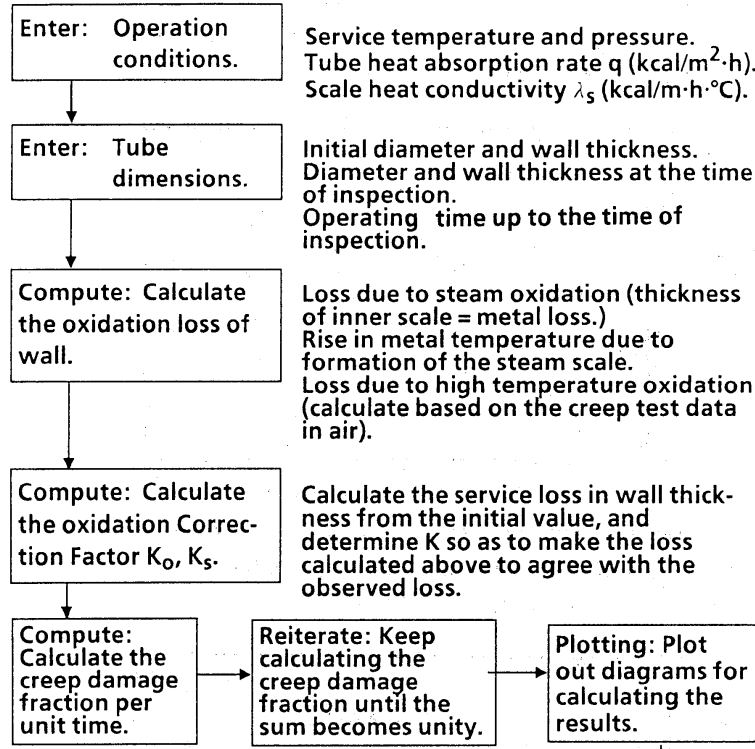

Checking: Compare the creep damage fraction calculated up to the time of inspection to the $N_{s b}$ value determined in TEM observation of the sample.

Comprehensive evaluation of residual service lifetime.

Determination of next inspection time or tube replacement time.

Fig. 12. Flow chart for evaluating creep damage accumulated in boiler heat transfer tubes. 


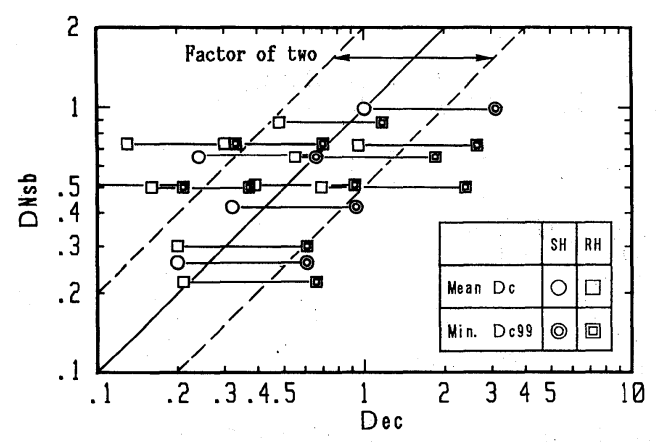

Fig. 13. Relationship between Dec and DNsb from correcting scale effect data. (DNsb: Evaluation damage from $\mathrm{Nsb}$ master curve)

Table II に実機使用材と損傷材の計算結果を示す. 管寸法は初期值を計測していないので設計条件から推 定した. 一方サンプリング材のクリープ損傷評価とし て TEM 観察による結晶粒内のサブグレイン形成率 $\left(N_{s b}\right)$ による損傷評価法で判定した。 その結果を $D N_{s b}$ で表示する.

Fig. 13 に個々の供試材の計算による損傷值 $D_{e c}$ と 組織観察による損傷値 $D N_{s b}$ の関係を示す。 $D_{e c}$ はク リープ強度の平均值を用いた平均值 $\left(D_{c}\right)$ と $99 \%$ 下限 值のクリープ強度を用いた最小值 $\left(D_{c} 99\right)$ で評価した 結果を示す。一部のデータを除いて $D_{c}$ と $D N_{s b}$ 雨者 の損傷比の対応が良くとれていることが分かる. $D N_{s b}$ が高い一部のものは $N_{s b}$ の測定誤差だと考えら れ，総合的に判断して $D_{e c}$ の方が信頼性が高いと考 えられた.このことから，両者を互いに比較検討する ことで, より正確な評価ができると共に, 余寿命も正 確に推定できると考えられる.

\section{4 結言}

$2.25 \mathrm{Cr} 1 \mathrm{Mo}$ 鋼ボイラ伝熱管の実機使用環境下の損 傷シミュレーション計算手法を開発して以下の結論が 得られた.

（1） ボイラ伝熱管の寿命消費曲線は下に凸の曲線に
なる、サンプリング材の破断データと初期条件による 従来の直線寿命評価法では，非安全側になる可能性が ある．余寿命評価には酸化スケールによる減肉，メ夕 ル温度上昇を考慮した損傷評価が重要である.

（2）過熱器管と再熱器管では, 収熱率の差により過 熱器管の方が水蒸気酸化スケールによる温度上昇量が 大きい. モデル計算結果では，過熱器管は使用時間が 長くなれば水蒸気酸化スケールによるメタル温度上昇 が大きくクリープ損傷評価が重要になり, 再熱器管は オーバヒートした場合, 酸化による減肉とメタル温度 上昇が加算されてクリープ損傷が大きくなり，管肉厚 の把握が重要である.

（3）実機使用材の損傷評価を行ったところ，計算に よる損傷值はクリープ強度が平均值で計算した $D_{e c}$ と TEMによる損傷評価 $D N_{s b}$ 值がほぼ同等の値が得 られ，両者の手法が妥当であることを示した.

(平成 5 年 5 月 26 日 日本材料学会第 42 期学術講演会にて講演)

\section{参 考 文 献}

1) ASME Sec. 1

2 ）村上晃一, 木原重光, 中代雅士，中川幸也, 石川島播磨 技報，31，353（1991）。

3 ）腐食防食協会編，“金属材料の高温酸化と高温腐食” （1982）丸善

4 ) 電中研報告書 CRIEPI-REPORT 227018, Dec. (1977).

5 ) 金子隆一, 本郷宏道, 長島伸夫, 門馬義雄, 田中千秋, CAMP-ISIJ, Vol. 1, 900 (1988)

6.) M. Nakashiro, S. Kihara, F. Kishimoto and T. Fujimori, ISIJ Inter. Vol. 30, 823 (1990).

7 ) I. M. Rehn, Corrosion Problems in Coal-Fired Boiler Superheater and Reheater Tubes, Steam-Side Oxidation and Exfoliation, EPRI CS1811 Project 644-1 (1981).

8 ) NRIM Creep Date Sheet No. 3B, Nat. Res. Inst. Met., Tokyo (1986),

9 ) M. Nakashiro and S. Kihara, 5th Int. Conf. on Creep of Material, Florida, 563 (1992). 